\title{
READERS
Insight
}

Journal of Management Info (JMI)

ISSN:2313-3376

www.readersinsight.net/jmi

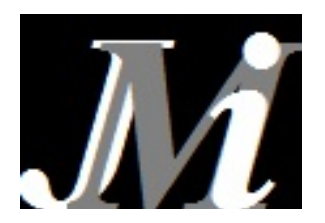

\section{Impact of customer relationship management on customer satisfaction in hoteling industry}

\author{
Sanaullah Nazir*1, Sheraz Khan², Raja Ahmed Jamil ${ }^{3}$, Qazi Shujaat Mehmood ${ }^{4}$ \\ 1,2,3, 4 Department Of Management Sciences, University Of Haripur
}

*Corresponding author: sanaullah@yahoo.com

\begin{abstract}
Customer satisfaction is an imperative element of the success for all businesses. One of the biggest challenges of a marketer is how to satisfy and retain the customers. The purpose of this study is to find the impact of customer relationship management on customer satisfaction. A total of 130 participants were selected through purposive sampling from different hotels of Islamabad city. Data was collected from the participants by using standardized questionnaires. Results revealed that there is a significant positive impact of different elements of customer relationship management (service quality, access to services and service features) on customer satisfaction and businesses cannot succeed without focusing on customer relationship management in this era.
\end{abstract}

\section{ARTICLE INFORMATION}

\section{Received: 25 March 2015 \\ Revised: 25 June 2015}

Accepted: 25 June 2015

DOI:

http://dx.doi.org//10.31580/jmi.v3i1.17

Keywords: Customer Relationship Management; Customer Quality; Access to Services; Service (C) Scholars ASIA Publication Features; Customer Satisfaction

\section{Introduction}

Customer relationship management has gained a considerable reputation in the recent times. It was seen through the theoretical perspective and empirical findings that elements of CRM like service quality and features lead to customer satisfaction which in turns lead to business profitability.

Customer relationship management (CRM) is a unique and important business approach. CRM entails all the aspects of interaction with customers with the help of technology to streamline the processes that impact service quality, customer's loyalty and customer satisfaction. The basic objective of CRM is to increase profitability, revenues and customer satisfaction.

\section{CRM basically consist of following three components}

Customer: The profit of any company is based on good customers and their inputs however there is a clear lack of a customer's interest, who gives more profit with limited resources. In this highly competitive market and availability of products and their knowledge is widespread which leads to confusion for the customers (Wyner, 1999 as cited in Paul, 2001).

Relationship: In terms of customers relation to the company is multidimensional based on mutual connection and communication which is possibly short or prolonged, last longer and remains continuous or can be distinct and customers manners and behavior are also related (Wyner, 1999 as cited in Paul, 2001).

Management: Management is to deal with humans or objects and in relation to human it describes itself a social phenomena which is obligates to consider the planning and regulations of a company in most appropriate and economical way by meeting the aims of a company as management is a active process which delivers energy in numbers of elements, these elements are totally differs from operative elements like purchase and expenditures moreover it also depends at managers abilities to and approach (Wyner, 1999 as cited in Paul,2001).

\section{Fundamental features}

Fundamental tools of CRM are very demanding and attract the customers because it covers marketing deep in service quality. Whereas with the help of these tools, an enterprise can maintain a customer's records to develop future relationship with the customers. Another key feature is the management that can access customer data base to check customer's history regarding previous visits, payment details, complaints etc. (Peelen, 2009)

\section{Customer satisfaction}

Customers satisfaction in other words is the customers experience with the product and its usefulness with the passage of time and reliability of the product is the only way which makes customers peace of mind where the service and reliability is high which directly improves the customers satisfaction however customers satisfaction is the only way which results in form of survival and progress and growth of the company (Kevin, 2000)

Satisfaction, the term satisfaction has its own sources and criteria in relation with the customers as some may be attracted by the service quality and some of them are impressed with the product quality anyhow the most affective things remains constant throughout which is cost effectiveness and performance of the product (Kevin, 2000)

\section{CRM and customer satisfaction}

The relationship between customer satisfaction and CRM is complex. Increased customer satisfaction is one of the CRM's promises. The measuring customer satisfaction serves to measure CRM return on investment. It also provides service and product quality feed back to other function (Allen, 2000). A symbiotic relationship exists between CRM and customer satisfaction measurement program. CRM programs generate sample for the customer satisfaction program. Customer feedback data is then recorded in the CRM system, assuming of course, that respondent permission has been procured (Allen, 2000). 


\section{Social significance}

This study will help the hotels in understanding the elements of CRM which lead to customer satisfaction which in twirl increased the profitability, customer loyalty and preservation. Numerous researches have been conducted on customer relationship management. But in Pakistan very a small number of companies know the value of customer relationship management, especially in hotel industry and very few follow a line of investigation about it. So we think that customer relationship needs special intension and also require a lot of hard work which will helpful for the future growth of the hotel industry.

\section{Literature review}

Light (2003) states that CRM is the most appropriate management tool which creates a relationship with customers in an organized forum where customer enjoys the (MOT) "Moment of truth" in accordance with the aim of CRM, where there hotels or other firms dealing with a customer at directly are called "touch point". Touch Points are considered important as these are the enrich source of customer feedback which directly helps hotel management to make policies which are more attractive to the customers. Concepts based on a happy customer with a relationship to the hotel likely stays with the firms.

A study was carried out by Abbasi et al. (2010) to find the factors associated with the hotel industry and of customer satisfaction in Pakistan. Responses were collected from the hotel customers of twin cities. They had given a 21 items like type questionnaire. A result states that the quality of service and features are the major factors of customer satisfaction which eventually leads to the future intentions of the customer.

A study has been conducted on customer satisfaction and mobile service provider and service quality within the Pakistan, and sample comprised over 331 young SMS service users which leads to positive consequences in terms of customer's satisfaction and customer relation Ahmad et al. (2010).

An investigative study has been conducted in Bangladesh top telecommunication company which tried to find out the effects of the customer's perception on quality of service, trust on the product of the company and overall satisfaction of customers where the results of the that study indicated the significant rise in customer satisfaction and trust in relation to customers loyalty Akbar and Pervez (2009).

A study reveals the customer satisfaction in light to the nature of customer and purpose which states that demand of customer satisfaction is to be greater over the goods, and customer and service are more in demand over the price or value of the product.

Fornell et al. (1996) discuss the nature and purpose of the American Customer Satisfaction Index and found that customer satisfaction to be greater than goods than for services and customer satisfaction is more quality driven than value or price driven. Customer expectations play a greater role in sectors in which variance in production and consumption is low.

Chang (2006) explores the relationship between service quality, customer satisfaction and loyalty in the Taiwanese Leisure Industry using a questionnaire method administered to visitors of Taiwan that visited the Yueh-Mei Sightseeing Sugar Mill. The results indicated that age and marital status did have a significant effect on the overall satisfaction as evaluated by the factors of service quality, customer satisfaction and loyalty. It indicated that married people were more satisfied than single people and that those aged 41-50 years were more satisfied that any other age groups in the study.

Fornell et al. (2005) evaluates the effect of Customer relationship Management on Customer Satisfaction. They used the data on key dependent and independent variables on separate sources to void common biased. The results indicated that there is positive relationship between Customer relation Management and customer satisfaction and knowledge.

Rampal \& Gupta (2006) defined service as identifiable, intangible activity that is the main object of a transaction designed to provide want satisfaction to consumer. Hospitality Services means receiving and attending guest with 'Bounteousness'. The Hotel Industry is a major part of Service Industry which is experiencing increased globalization, competition, higher customer turnover, growing customer acquisition costs and rising customer expectation, meaning that hotel's performance and competitiveness is significantly dependent on their ability to satisfy customer efficiently and effectively. Customer Satisfaction can be measured through level of Service Quality provided to the Customers. Ahmed \& Jawaberh (2012) studied the Impact of Customer Relationship Management on Hotel (A Case study Umaid Bhwan) in India (Indore region) using data from customer. The results revealed that there is positive impact of customer relationship Management on customer trust and satisfaction with medium degree in Umaid Bhwan hotel.

Gilaninia et al. (2011) studied the CRM application impact on customer satisfaction in financial and credit institutions. They adopted the descriptive method of study - analytical and causal analysis and statistical community is customers of financial and credit institutions in Iran (Guilan) and measurement tools is questionnaires. Regression analysis was run and found that the elements of CRM (quality of service, service features, and service availability and system complaints) have an impact on customer satisfaction. Rajput \& Singh (2010) developed and standardized a measure to evaluate the importance of customer relationship management in hospitality services and its impact on customer satisfaction. 200 respondents from the Indore region were selected. The results showed a significant and positive relationship between Customer relationship management and customer satisfaction.

Lien (2010) examined the relationship between service quality, guest satisfaction and guest behavioral intentions. The respondents were guests who stayed in hotels in Ho Chi Minh City, Vietnam. First, the research proposed a model analyzing the effect of service quality factors in hotel industry on perceived service quality. Results showed that perceived service quality has a positive effect on guest satisfaction and guest behavioral intentions. Andreson et al. (1994) investigate the link between service quality and customer satisfaction. They used national customer satisfaction index and traditional accounting measures. The results showed a positive impact of quality on customer satisfaction and in turn profitability.

The purpose of the present study was to explore the impact of customer relationship management in the hotel industry on customer satisfaction in Pakistan. Based on the extant literature, it was hypothesized that customer relationship management would be positively associated with customer satisfaction. The present study undertakes following objectives.

To find the impact of customer relationship management on customer's satisfaction.

To identify the differences of the impact of customer relationship management of customers due to their demographic information.

\section{Methodology}

According to the purposes and literature reviews on above, the study presents a research structure in the conceptual framework. Quality of services, access to services and service feature is the independent variable, customer satisfaction is the dependent variable.

\section{Hypotheses}

H1: Service quality has a positive significant impact on customer satisfaction.

H2: Access to services has a positive and significant impact on customer satisfaction.

H3: Service features have a positive and significant impact on customer satisfaction.

\section{Conceptual framework}

Fig. 1 shows conceptual framework for the current study. 
Independent variable

Dependent variable

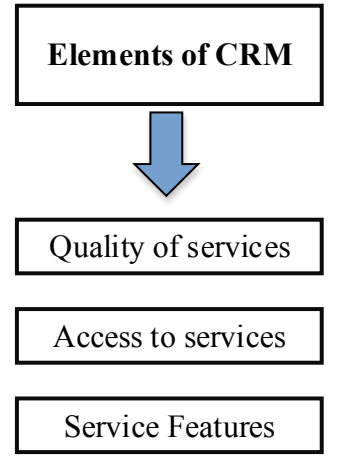

Fig. 1. Conceptual Framework

\section{Sampling}

The purposive sampling technique was used in the present study because of the limited time available for data collection."Purposive sampling can be defined as a type of nonprobability sampling in which element to be included in the sample are selected by the investigator on the basis of special characteristics of respondent" (Shaughnessy and Zechmiester, 1994). Customers who visited famous hotels in Islamabad were selected for the present study. Of the total 130 customers included in the study, 95 were males and 35 were females.

\section{Instruments}

The following instruments were used in this research: Questionnaire was developed by Rajput \& Singh (2010) are used for the evaluation of Customer Satisfaction and impact of CRM on satisfaction. It has 30 items and use Likert Type Scale, where in Customer Relationship 5 stands for Strongly Agree and 1 stands for Strongly Disagree and in Customer Satisfaction 5 stands for High Satisfaction and 1 Stands for High Dissatisfaction. The customer relationship is measured in four areas i.e., service quality ( $\mathrm{Q} 1,2,7,13,14,15,16)$, access to services(Q 3,8,9,10,11) and service features( $\mathrm{Q} 4,5,6,12)$. The internal consistency of the scale was indicated by the alpha coefficient value of 0.936 . The face validity was checked and found to be high.

\section{Demographic questionnaire}

The Demographic Questionnaire was prepared by the researcher in order to get important information about participant's age, gender and social status.

\section{Procedure}

\section{Pilot study}

A pilot study was conducted on 10 participants ( 5 female and 5 males) age ranging from 15- 46 and above years from hotels in Islamabad... The purpose of the pilot study was to see the understandability and conceptual clarity of items of all questionnaires and the total time taken in the administration. They were informed about the nature and purpose of research and the procedure of administration of research tools. No major difficulty in understand ability of tools was reported. The average time taken to complete all tools was $10-15$ minutes.

\section{Main study}

In main study 130 participants were originally recruited from different hotels of Islamabad. The data were collected in-group settings. The same administration procedure was followed as was used in the pilot study. The purpose of the study was made clear to participants and proper instructions were given. It was made clear to the participants that the data would be used only for research purposes, confidentiality will be maintained and they can quit participation in research if they do not feel like participating at any time. Whenever they had doubts in understanding questions, the researcher made this very clear question to them by providing a standard alternative. On average the administration took 10-15 minutes. The participants were motivated in completing the questionnaires and showed interest in the study.

\section{Statistical analysis}

Using SPSS (version 21.0) statistical package, descriptive analysis, Pearson product moment correlation and linear regression were computed to find out the relation and dependence between different variables.

\section{Results}

The purpose of the study was to determine the impact of customer relationship management on customer satisfaction in the hotel industry. Descriptive analysis was carried out for demographic variables. Pearson product moment correlation was employed to carry out a correlation between different variables and linear regression was applied to portray the dependence of one variable on other variables.

Table 1: Distributions of Male and Female participants in Different Age Groups

\begin{tabular}{lllll}
\hline Age & Male & $\mathbf{N}=\mathbf{9 5}$ & Female & $\mathbf{N}=\mathbf{3 5}$ \\
\hline & $\mathrm{f}$ & $\%$ & $\mathrm{~F}$ & $\%$ \\
$15-25$ & 25 & 26 & 11 & 31 \\
$26-35$ & 30 & 31 & 14 & 40 \\
$36-45$ & 27 & 28 & 7 & 20 \\
$46 \&$ above & 13 & 13 & 3 & 9 \\
\hline
\end{tabular}

Most of the participants from the two gender groups belonged to the age group, $26-35$ years.

Table 2: Distributions of Male and Female Participants in Different Social Status

\begin{tabular}{lllll}
\hline Demographics & Male & $\mathbf{N}=\mathbf{9 5}$ & Female & $\mathbf{N}=35$ \\
\hline & $\mathrm{f}$ & $\%$ & $\mathrm{~F}$ & $\%$ \\
Business Class & 30 & 32 & 2 & 6 \\
Service Class & 51 & 54 & 14 & 40 \\
Student & 14 & 15 & 5 & 14 \\
Housewife & & & 14 & 40 \\
\hline
\end{tabular}

Mostly the participants belong to the service class. Number of males belong to business is higher than females.

Table 3: Correlation of Customer Satisfaction with Service Quality, Service Feature and Access to Services

\begin{tabular}{ll}
\hline Customer Satisfaction & $\mathrm{n}=130$ \\
\hline Service Quality & $.361^{\star \star}$ \\
Service Feature & $.416^{\star *}$ \\
Access of Service & $.499^{\star *}$ \\
\hline${ }^{*}=P<0.01$ &
\end{tabular}
${ }^{* *}=\mathrm{P}<0.01$

The significant correlation between customer satisfaction, service quality, service feature and access to services depicted that the high level of service quality, service feature and access to service leads to high level of customer satisfaction.

Table 4: Showing linear Regression Analysis, Customer Satisfaction as the Dependent Variable (Services)

\begin{tabular}{llll}
\hline Independent Variables & Adjusted R Square & $\boldsymbol{\beta}$ & $\mathbf{t}$ \\
\hline Service Quality & .298 & .201 & $2.546^{*}$ \\
Service Feature & .298 & .187 & $3.631^{* *}$ \\
Access of Service & .298 & .329 & $2.127^{*}$ \\
\hline${ }^{*}=\mathrm{P}<0.01{ }^{*}=\mathrm{P}<0.05$ & &
\end{tabular}

$\frac{\text { Access of Service }}{{ }^{*}=\mathrm{P}<0.01,{ }^{*}=\mathrm{P}<0.05}$

The results demonstrate that the $30 \%$ of customer satisfaction in hotel industry depends on the three independent variables of our study. The coefficient of determination and $t$ values show significant relatedness.

\section{Discussion}


The goal of the present study was to examine the impact of customer relationship management on customer satisfaction in the hotel industry. The present chapter will discuss sample characteristics and main findings of the present research in the light of current available literature. Mean age of the females was lower than males, possibly due to less number of females in the sample.

Hypothesis one, stated that service quality has a positive significant impact on customer satisfaction. The results supported the hypothesis. The result is in line with the previous studies. A number of studies (Abbasi et a, 2010; Ahmed et al, 2010; Chang, 2006; Gilaninia et al.2011; Lien 2010; Andreson, Fornell \& Lehmann, 1994) also found that service quality has positive impact on customer satisfaction. As the service quality increased, the level of overall customer satisfaction also increased quality, deemed essential by customers, could be the key to customer satisfaction.

The second hypothesis was that access to services has a positive and significant impact on customer satisfaction was supported by the results. The present findings also corroborated with the various studies (Gilaninia et al., 2011; Ahmed, Jawaberh, 2012). In hotel industry access to services is crucial to the satisfaction of the customers.

The next hypothesis stated that the service features have a positive and significant impact on customer satisfaction was supported by the results. This result is in line with the previous work carried out in customer relationship management and customer satisfaction studies (Gilaninia et al, 2012). Service features proved to be an important antecedent of customer satisfaction.

\section{Conclusion}

The findings of the present study reflect that an element of customer relationship management (quality of services, access to services and service features) have a significant and positive impact of customer satisfaction. When the customers feel satisfied with the service quality and features, it will lead to their behavioral intentions, such as recommending this hotel to others, they would like to come back to this hotel in the future even the prices are higher.

\section{Limitations}

In conducting this study, efforts were made to minimize its limitations, but there are some still need to be addressed. Results should be interpreted with the conditions, as there is the limitation that purposive sampling was taken in the present study. Future research with randomly selected from more big areas in Pakistan, the sample could provide a more comprehensive coverage.

The second limitation is the research was targeted at the Islamabad Hotel industry; this study did not investigate the impact on types of hotels ( 1 star, 2 stars, 3 stars, 4 stars, 5 stars) of guests in their hotel stays and their satisfaction.

\section{Implications}

This is intended to be useful contribution to understand the importance of customer relation on customer satisfaction. This study will also be useful for those hotels who want to conduct research for knowing the correlation of customer relation with customer satisfaction; they will be able to solve several problems related to their customers. It also contributes to the related industry in helping them by knowing about the effect of customer relation on customer satisfaction.

\section{Future research}

In future same relationship needs to be investigated by taking random and more representative sample and to get more generalized results. Further research needs to be conducted in Pakistan to explore more variables, which may affect the customer satisfaction in other sectors.

\section{References}

Alipour, H., Gilaninia.S.Khosoosi, Z.E. (2011). CRM Application Impact on Customer Satisfaction in Financial and Credit Institutions. Journal of Basic and Applied Scientific Research, 1(8), 956-963.

Ahmed, T., Almomani, A.,\& Jawaberh, O.A.A(2012).Impact of Customer Relationship Management of Hotel (A Case study Umaid Bhwan).Asian Journal of Finance \& Accounting, 4,1.

Anderson, W., Fornell, C., \&Lehmann, R. (1994). Customer satisfaction, Market Share, and Profitability: Findings from Sweden. Journal of Marketing, 58, 53-66.

Abbasi, S.A., Azam, M., Khalid, W., \&Riaz, A. (2010). Determinants of Customer Satisfaction in Hotel Industry of Pakistan. European Journal of scientific Research, 48, 1, 97-105.

Allen, R. (2000). Customer satisfaction Research, A comprehensive guide to integrating customer loyalty and satisfaction matrices. American society for quality.

Akbar \& Pervaiz. (2009). Impact of Service quality, Trust, and customer Satisfaction on Customer loyalty.ABAC journal 29, No 1, .24-38.

Chang, H. (2006). A Study of service quality, customer satisfaction and Loyalty in Taiwanese Leisure industry. Journal of American Academy of Business, 9(1), 126-133.

Fornell, C., Micheal, D., Andreson, W., Cha, J., \&Bryant, B. (1996). The American Customer Satisfaction Index: Nature, Purpose, and Findings. Journal of Marketing, 60, 7-18.

Fornell, C., Mithas, S., \& Krishnan, M.S. (2005). Why Do Customer Relationship Management Applications Affect Customer Satisfaction. Journal of Marketing, 69,201-209.

Jaipuria, A. (2006). The Dark Side of Customer Relationship Management in the Luxury Segment of the Hotel Industry.MA Management University of Notingham.

Kamkura, A.W., \& Mittal, V. (2001). Satisfaction, Repurchase Intent, and Repurchase Behavior: Investigating the Moderating Effect of Customer Characteristic. Journal of Marketing Research, XXXVIII, 131-142.

Kevin Cacioppo, (2000).Customer Satisfaction. Retrieved from http://www.qualitydigest.com/sept00/html/satisfaction.html

Light, B. (2003). CRM packaged software: A study of organizational experiences. Business

Process Management Journal, 9, 303-316.

Lien, H.(2010), An Understanding the Impact of Service quality on Guest Satisfaction and guest Behavioral Intentions in Vietnam Hotel Industry. Southern Taiwan University, Master Thesis.

Peelen, Ed. (2009). Customer relationship Management. Dorling Kindersely (India) Put Ltd.

Paul, G., \&Jonbok, B. (2001).Customer Relationship Management. Retrieved from http://escholarship.org/uc/item/76n $7 \mathrm{~d} 23$ 


\section{Appendix}

Impact of CRM on Customer Satisfaction in Hotel Industry.

Dear respondent, we are undergoing a research to find the impact of Customers Relationship Management on Customer Satisfaction in Hotel industry. The Questionnaire that follows is a tool for collection of data for the project. Your are requested to tick the option that best shows your option that best shows your preference and please pay attention to respond the questions and help it to be of high validity. It is hoped that the result from this research is used in giving services better and more. The information provided will be used for research purpose only will kept confidential.

\section{Demographic Variables}

Gender: Male (

Age: (

(a) $15-25 \mathrm{yrs}$

(b) 26-35 yrs

(c) $36-45$ yrs

(d) $46 \&$ above
Female ( )
(a) Business Class
(b) Service Class
(c) House Wife
(d) Student

\begin{tabular}{|c|c|c|c|c|c|}
\hline QUESTIONS: (5=highly Agree, $4=$ Agree, $3=$ Neutral, $2=$ Disagree, $1=$ Highly Disagree) & 5 & 4 & 3 & 2 & 1 \\
\hline Hotel should be registered with some reliable group & 5 & 4 & 3 & 2 & 1 \\
\hline Hotel ones visited by me will be preferred for next visit & 5 & 4 & 3 & 2 & 1 \\
\hline Hotel's web site always helps a person to know more about the Hotel & 5 & 4 & 3 & 2 & 1 \\
\hline Hotels should have online reservation system & 5 & 4 & 3 & 2 & 1 \\
\hline Chain business Hotels are more visited & 5 & 4 & 3 & 2 & 1 \\
\hline Only Token money at the time of booking should be asked & 5 & 4 & 3 & 2 & 1 \\
\hline Lifts and elevators are requir4ed for a comfortable stay & 5 & 4 & 3 & 2 & 1 \\
\hline Hotels with prompt conveyance facility helps customer's visit & 5 & 4 & 3 & 2 & 1 \\
\hline $24 \mathrm{hrs}$ communication facility is required & 5 & 4 & 3 & 2 & 1 \\
\hline Location near the city is preferred & 5 & 4 & 3 & 2 & 1 \\
\hline Different mode of payment is required & 5 & 4 & 3 & 2 & 1 \\
\hline Hotel exclusively meant for lodging and boarding makes stay more comfortable & 5 & 4 & 3 & 2 & 1 \\
\hline Food should be served with quality and variety & 5 & 4 & 3 & 2 & 1 \\
\hline Electric appliances in the room has to be properly checked regularly & 5 & 4 & 3 & 2 & 1 \\
\hline The well furnished rooms are expected & 5 & 4 & 3 & 2 & 1 \\
\hline Ambience of the hotel must remain good & 5 & 4 & 3 & 2 & 1 \\
\hline
\end{tabular}

\begin{tabular}{|c|c|c|c|c|c|}
\hline $\begin{array}{l}\text { QUESTIONS: }(5=\text { high Satisfaction, } 4=\text { Satisfaction, } 3=\text { Neutral, } 2=\text { Dissatisfaction, } \\
\text { l=Highly Dissatisfaction })\end{array}$ & 5 & 4 & 3 & 2 & 1 \\
\hline The staff understanding English as well as Urdu makes stay more easy & 5 & 4 & 3 & 2 & 1 \\
\hline Employees in uniform gives a pleasant look & 5 & 4 & 3 & 2 & 1 \\
\hline Promptness in Room Services at a single call is more satisfying & 5 & 4 & 3 & 2 & 1 \\
\hline Hotel should be trust worthy and safe as far as honesty of personnel is concerned & 5 & 4 & 3 & 2 & 1 \\
\hline Any problem when informed to the manager is expected to be solved immediately & 5 & 4 & 3 & 2 & 1 \\
\hline The staff following all the instruction given by customer is more appreciable & 5 & 4 & 3 & 2 & 1 \\
\hline Feedback asked from the customers explain the customer importance & 5 & 4 & 3 & 2 & 1 \\
\hline The hotel sending the season's greetings help in remembering the hotel for long time & 5 & 4 & 3 & 2 & 1 \\
\hline $24 \mathrm{hrs}$ online booking is a strong point for hotel & 5 & 4 & 3 & 2 & 1 \\
\hline Accepting reserve cancellation by hotel is of important consideration for customers. & 5 & 4 & 3 & 2 & 1 \\
\hline $\begin{array}{l}\text { Advertising about the discounts and special prices of each season by hotel could be a factor for reselecting the } \\
\text { hotel }\end{array}$ & 5 & 4 & 3 & 2 & 1 \\
\hline Receiving welcome note adds to customer satisfaction & 5 & 4 & 3 & 2 & 1 \\
\hline Giving priority to privacy is one important factor for satisfaction in stay & 5 & 4 & 3 & 2 & \\
\hline Personnel's appropriate behavior is one of the effective factor in next stays of the customer & 5 & 4 & 3 & 2 & 1 \\
\hline
\end{tabular}

Personnel's appropriate behavior is one of the effective factor in next stays of the customer

Thank You for participation. 